\title{
Turkish Adaptation of the Workplace Breastfeeding Support Scale: A Validity and Reliability Study
}

İşyeri Emzirme Desteği Ölçeğinin Türkçe Uyarlaması: Geçerlik ve Güvenirlik Çalışması

Neşe KARAKAYA ${ }^{1}$, Meral KILIÇ²

1Ondokuz Mayıs Üniversitesi Sağlık Bilimleri Fakültesi, Ebelik Bölümü,
•nese.karakaya28@gmail.com • ORCiD > 0000-0002-6125-6291

${ }^{2}$ Atatürk Üniversitesi Sağlık Bilimleri Fakültesi, Ebelik Bölümü

•m_kavak25@hotmail.com• ORCID > 0000-0001-9770-7448

\author{
Makale Bilgisi / Article Information \\ Makale Türü / Article Types: Araştırma Makalesi / Research Article \\ Geliş Tarihi / Received: 28 Kasım / November 2021 \\ Kabul Tarihi / Accepted: 6 Aralık / December 2021 \\ YIl / Year: 2021 | Cilt - Volume: 6 | Sayı - Issue: 3 | Sayfa / Pages: $721-736$
}

Atıf/Cite as: Karakaya, N. ve Kılıç, M. “Turkish Adaptation Of The Workplace Breastfeeding Support Scale: A Validity And Reliability Study- Işyeri Emzirme Desteği Ölçeğinin Türkçe Uyarlaması: Geçerlik ve Güvenirlik Çalışması”. Samsun Sağlık Bilimleri Dergisi- Journal of Samsun Health Sciences 6(3), Aralık 2021: 721-736. https://doi.org/10.47115/jshs.1029188 Sorumlu Yazar:: Neşe KARAKAYA 


\section{TURKISH ADAPTATION OF THE WORKPLACE BREASTFEEDING SUPPORT SCALE: A VALIDITY AND RELIABILITY STUDY}

\section{ABSTRACT:}

Aim: This study was conducted to adapt the "Workplace Breastfeeding Support Scale" into Turkish and evaluate psychometric properties.

Method: Two hundred twenty-five volunteering women aged 18 and over, working in the public sector for at least one month after the leave, having an infant aged 4-12 months, having breastfed for a while or still breastfeeding were included in the study. IBM SPSS version 22.0 and AMOS 20 programs were used for data analysis. For explanatory factor analysis (EFA), principal component, varimax vertical rotation and scree plot test were performed. Structural equation modeling (SEM) was performed for confirmatory factor analysis (CFA).

Results: It was determined that Cronbach's alpha coefficient of the scale was 0.78 , the item-total score correlations ranged between 0.26 and 0.65 , and no item was removed from the scale. It was confirmed that the scale had a 2-factor structure as a result of EFA, and the validity of the 2 -factor structure was confirmed by CFA, and the $\chi^{2} / \mathrm{df}$ ratio was 1.928 , RMSEA value was 0.064 , GFI value was 0.929 , AGFI value was 0.896 , and TLI was 0.908 . The correlation value of the relationship between the first and second measurement results of the scale was $r=0.932$, and the value between the two measurements was found to be highly significant $(\mathrm{p}<0.001)$.

Conclusion and Suggestions: The Turkish version of the Workplace Breastfeeding Support Scale was found to be a valid and reliable measurement tool. It is recommended that the Workplace Breastfeeding Support Scale, which was adapted into Turkish, should be tested in mothers working outside the public sector or in different samples.

Keywords: Breastfeeding; Workplace; Breastfeeding Support; Validity; Reliability 


\title{
IŞYERI EMZIRME DESTEĞi ÖLÇEĞiNIN TÜRKÇE UYARLAMASI: GEÇERLIK VE GÜVENIRLIK ÇALIŞMASI
}

\begin{abstract}
Öz:
Amaç: Bu çalışma, İşyeri Emzirme Desteği Ölçeğinin Türkçe'ye uyarlanması ve psikometrik özelliklerinin değerlendirilmesi amacıyla yapılmıştır.

Yöntem: Araştırmaya 18 yaş ve üzeri, izinler sonrası en az bir aydır kamuda çalışıyor olan, bebeği 4-12 ay arasında olan, bir süre emzirmiş veya emziriyor olan gönüllü 225 kadın dâhil edilmiştir. Verilerin analizi için IBM SPSS 22.0 versiyonu ve AMOS 20 programları kullanılmıştır. Açıklayıcı faktör analizi (AFA) için temel bileşen, varimax dikey döndürme ve scree plot testi, Doğrulayıcı faktör analizi (DFA) için yapısal eşitlik modellemesi (YEM) yapılmıştır.

Bulgular: Ölçeğin Cronbach’s alfa katsayısının 0.78, madde-toplam puan korelasyonlarının 0.26-0.65 arasında değiştiği belirlenmiş ve ölçekten herhangi bir madde çıkarılmamıştır. AFA sonucunda ölçeğin 2 faktörlü bir yapısının olduğu, DFA ile 2 faktörlü yapısının geçerli olduğu doğrulanmış ve $\chi^{2} / S D$ oranı 1.928 , RMSEA değeri 0.064, GFI değeri 0.929, AGFI değeri 0.896 ve TLI $=0.908$ olarak bulunmuştur. Ölçeğin birinci ve ikinci ölçüm sonuçları arasındaki ilişkiye ait korelasyon değeri $\mathrm{r}=0.932$ olup iki ölçüm arasındaki değer ileri düzeyde $(\mathrm{p}<0.001)$ anlamlı bulunmuştur.
\end{abstract}

Sonuç ve Önerileri: İşyeri Emzirme Desteği Ölçeğinin Türkçe formunun geçerli ve güvenilir bir ölçme aracı olduğu saptanmıştır. Türkçe'ye uyarlanan İşyeri Emzirme Desteği Ölçeğinin kamu dışında çalışan annelerde veya farklı örneklemlerde denenmesi önerilmektedir.

\section{Anahtar Kelimeler: Emzirme; İş yeri; Emzirme Desteği; Geçerlik; Güvenirlik}

\section{INTRODUCTION}

Breastfeeding is a unique method for the healthy growth and development of a newborn individual. Because of the many beneficial health consequences of breastfeeding for both the mother and infant, the American Academy of Pediatrics recommends that all infants be exclusively breastfed for 6 months and then breastfed with the addition of solid foods for at least 1 year (Eidelman \& Schanler, 2012).

Nowadays, many women return to work after giving birth and need national policy and legislation such as paid maternity leave, breastfeeding leave, or breastfeeding breaks to continue breastfeeding (Eroğlu \& Yurtsal, 2018). A working 
woman spends at least one-third of her day at work, making it difficult for her to breastfeed her infant. After a while, working mothers experience breastfeeding problems and stop breastfeeding early, or their infants refuse to suck (Eroğlu \& Yurtsal, 2018). The flexibility of working hours and working conditions at work are important determinants for mothers to continue breastfeeding (Eren et al., 2018). It is known that the risk of premature cessation of breastfeeding is higher in mothers who return to work and do not receive professional support individually (Gianni et al., 2019). It is suggested that mothers who have access to break times and breastfeeding rooms at work are 2.3 times more likely to breastfeed exclusively for six months (Kim, Shin, \& Donovan, 2019). The American College of Obstetricians and Gynecologists (ACOG) argues that policies that protect the rights of the mother and infant, such as paid breastfeeding leaves, infant care in the workplace, and the allocation of non-bathroom rooms for breastfeeding, are crucial in maintaining breastfeeding (ACOG, 2016). Along with the policies to be developed regarding workplace breastfeeding support, positive communication between employees and managers can also increase workplace breastfeeding support (Anderson et al., 2015). Bai and Wunderlich believe that working mothers' experiences regarding work, family, and breastfeeding will improve when support is provided by both healthcare professionals and employers (Bai \& Wunderlich, 2013).

The absence or implementation of policies for breastfeeding in the workplace, the inflexible working environment, shift work, and the inconvenience of the working environment for breastfeeding adversely affect the duration of breastfeeding. Although a suitable environment and time for breastfeeding mothers in the working environment are provided with very little cost and effort, many mothers experience difficulties due to the lack of this environment in the workplace (Eroğlu \& Yurtsal, 2018; Lee, 2017). The United States Breastfeeding Committee (USCB) confirms that conditions at work have a significant impact on breastfeeding. A supportive workplace plays a central role in a woman's ability to continue breastfeeding (Eroğlu \& Yurtsal, 2018). Factors such as flexible work schedules, organizational policies, employer training, and workplace breastfeeding programs improve the ability of working mothers to continue breastfeeding when they return to work (Bruk-Lee et al., 2016). Employers need to implement policies and legislation to support their breastfeeding employees and create a supportive environment in the workplace (Haviland et al., 2015). In recent years, UNICEF and WHO have recommended that maternity leave and breastfeeding breaks be prioritized for working mothers and that higher budgets be allocated and infrastructure be established to accept workplace breastfeeding support (UNICEF, 2019), and they have emphasized breastfeeding support with the slogan "Breastfeeding isn't just a one-woman job" in the "Global Breastfeeding Collective" statement in 2019 (UNICEF, 2017). It is very important for working mothers to continue breastfeeding effectively in terms of both maternal and infant health. It cannot be ignored that these two im- 
portant factors will seriously affect public health. Since health and economy are interconnected, the effectiveness of policies that will encourage the continuation of breastfeeding will increase both health and economic welfare.

In Turkey, workplace breastfeeding support is a new concept, and there is no measurement tool to evaluate it. The research was conducted to adapt the "Workplace Breastfeeding Support Scale" into Turkish and evaluate psychometric properties.

\section{METHODS}

Design: The research was carried out to adapt the Workplace Breastfeeding Support Scale, which is used to determine the perception of workplace breastfeeding support in working mothers, into Turkish. This design enabled us to determine that the original scale was a valid and reliable tool for Turkish society.

Place and Time of Research: September 2019-Dec 2019 The research was conducted in three major public institutions in northern Turkey.

Sample: Mothers aged 18 and over, working in the public sector for at least one month after the leave, having an infant aged 4-12 months, having breastfed for a while or still breastfeeding were included in the study. The Workplace Breastfeeding Support Scale consists of 12 items. In scale adaptation studies, the sample size should be at least 5-10 times the number of scale items (Büyüköztürk, 2006). Before the research, the sample size was calculated by applying the biserial correlation power analysis test in the $\mathrm{G}$ Power program. In the power analysis, the sample size was found to be 180 with $95 \%$ (1- $\alpha$ ) confidence and 100\% (1- $\beta$ ) test power, but 225 women were included in the study, considering that there might be data loss.

\section{Data Collection Tools}

Socio-Demographic Information Form: In the form prepared by the researchers, there are questions about age, education level, family structure and income status.

Workplace Breastfeeding Support Scale (WBSS): The Workplace Breastfeeding Support Scale was first developed by Bai, Peng, and Alyce to establish the perception of workplace breastfeeding support in working mothers in the United States. Cronbach's alpha value of the scale was 0.77 , and the correlation value was $r=0.86$ (Bai, Peng, \& Fly, 2008). The scale consists of 12 items and Likert-type response options. It is required to mark the appropriate number (1-7) between the responses in the scale between "strongly disagree" and "strongly agree". In this study, Cronbach's 
alpha coefficient was found to be 0.78 for the Turkish version of the WBSS.

Adaptation of the Workplace Breastfeeding Support Scale into Turkish: For language validity, the scale, whose original language was English, was translated into Turkish by four experts. The scale, checked by the researchers, was translated back into English by four different experts. To evaluate the content validity, 9 experts provided their opinions on the form created using the Davis technique. The Context Validity Index (CVI) score of the scale, which was adapted into Turkish, was calculated as 0.97 . A pilot study was conducted with 40 people. The final adjustment of the scale was made, taking into account the opinions of the participants and experts.

Data Collection: The WBSS form, whose language and content validity was completed, was applied to the volunteer participants between September 2019 and December 2019 with face-to-face interviews conducted by the researchers in the institution where they worked. Data collection took approximately 5-10 minutes. The same form was applied again to 30 volunteer participants who were included in the test-retest 15 days after the first application. Ethics committee permission (decision no. 2019/548) and institutional permissions were obtained for the research.

Data Analysis: The data analysis was carried out with the "IBM SPSS for Windows 22.00 " statistical package, and the confirmatory factor analysis was carried out with the "AMOS 20" software package. For explanatory factor analysis (EFA), Principal Component, Varimax Vertical Rotation and Scree Plot Test were performed. The normality distribution of the data was determined by skewness and kurtosis analyses and the Z-test. Structural equation modeling (SEM) was performed for confirmatory factor analysis (CFA). Correlations of the WBSS and its sub-dimensions with each other and with the overall scale, their Cronbach's alpha coefficients, arithmetic means, standard deviations and ranges were calculated.

\section{RESULTS}

It was found that $53.3 \%$ of the participants had an undergraduate degree, $92.9 \%$ had a nuclear family structure, $45.8 \%$ had an income equal to their expenses, and their mean age was $32.54 \pm 4.30$ years.

The fact that the KMO coefficient, calculated for the content validity of the scale whose language validity was performed, was 0.79 and the chi-square was $\left(\chi^{2}\right)=717.023(\mathrm{p}<.000)$. Anti-image correlation values were positive and significant in all of the scale items (Measures of Sampling Adequacy-MSA). 
Table 1. Total variance described for the breastfeeding support scale

\begin{tabular}{|l|l|l|l|l|l|l|}
\hline \multicolumn{7}{|c|}{ Initial Eigenvalues Sum of Squares of Loads } \\
\hline Component & Total & \% of Variance & $\begin{array}{l}\text { Cumulative } \\
\%\end{array}$ & Total & \% of Variance & $\begin{array}{l}\text { Cumulative } \\
\%\end{array}$ \\
\hline 1 & 3.768 & 31.396 & 31.396 & 3.363 & 28.024 & 28.024 \\
\hline 2 & 1.961 & 16.340 & 47.736 & 2.365 & 19.712 & 47.736 \\
\hline 3 & .986 & 8.215 & 55.952 & & & \\
\hline 4 & .899 & 7.489 & 63.441 & & & \\
\hline 5 & .761 & 6.344 & 69.785 & & & \\
\hline 6 & .735 & 6.125 & 75.910 & & & \\
\hline 7 & .634 & 5.287 & 81.197 & & & \\
\hline 8 & .579 & 4.825 & 86.022 & & & \\
\hline 9 & .508 & 4.236 & 90.258 & & & \\
\hline 10 & .450 & 3.751 & 94.009 & & & \\
\hline 11 & .437 & 3.638 & 97.646 & & & \\
\hline 12 & .282 & 2.354 & 100.000 & & & \\
\hline
\end{tabular}

Extraction Method: Principal Component Analysis

Principal component and varimax rotation methods were applied to the Workplace Breastfeeding Support Scale, consisting of 12 items. After the factor analysis of the scale, it was determined that it had a 2-factor structure that explained $47.73 \%$ of the total variance (Table 1 ). The factor loads of the items of the scale, to which the Varimax rotation method was applied, range from 0.49 to 0.77 .

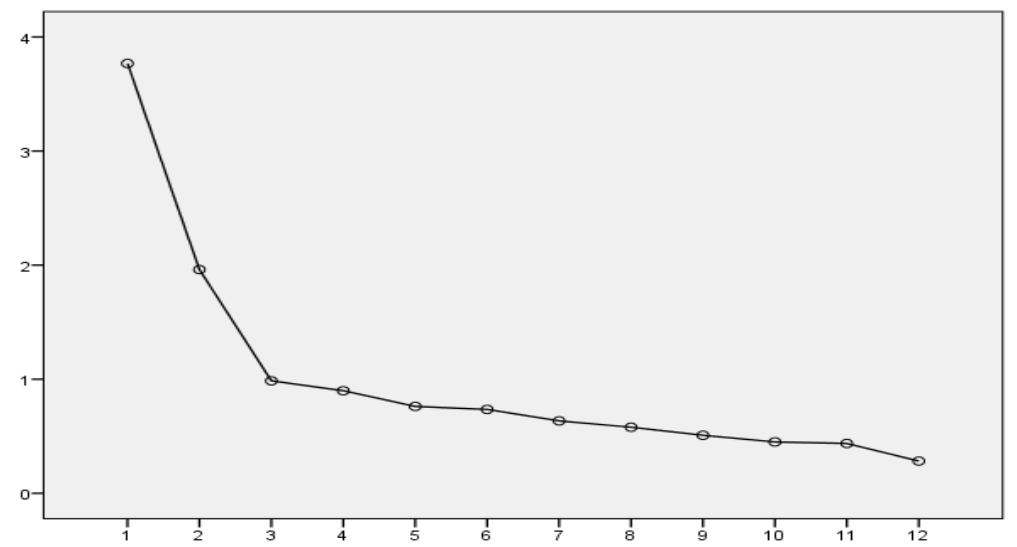

Figure 1. Scree Plot 
The first sudden change after the number 1 in the eigenvalue of the graph that emerged as a result of the scree plot test appeared in Factor 2 (Fig.1).

Table 2. Distribution of the items of the workplace breastfeeding support scale by factors

\begin{tabular}{|c|c|c|}
\hline & 1 & 2 \\
\hline \multicolumn{3}{|l|}{ Peer and Environmental Support } \\
\hline $\begin{array}{l}\text { 1-My co-workers agree that breastfeeding is better for baby's } \\
\text { health than formula feeding. }\end{array}$ & .638 & \\
\hline $\begin{array}{l}\text { 2- I have supportive co-workers who cover for me when I } \\
\text { need to pump my milk. }\end{array}$ & .668 & \\
\hline $\begin{array}{l}\text { 3- My co-workers do not make fun of me when I sometimes } \\
\text { leak milk through my clothes. }\end{array}$ & .618 & \\
\hline 4- Breastfeeding is common in my workplace. & .695 & \\
\hline 5- I have a breastfeeding supportive supervisor. & .750 & \\
\hline $\begin{array}{l}\text { 6- My co-workers listen to me talk about my breastfeeding } \\
\text { experience. }\end{array}$ & .721 & \\
\hline $\begin{array}{l}\text { 7-I feel comfortable taking several breaks during work hours } \\
\text { to pump breast milk. }\end{array}$ & .593 & \\
\hline \multicolumn{3}{|l|}{ Facility Support and Technical Support } \\
\hline $\begin{array}{l}\text { 8- In my workplace, there is a designated space (nursing } \\
\text { room) to nurse my baby or pump breast milk. }\end{array}$ & & .745 \\
\hline $\begin{array}{l}\text { 9- I can easily find a quite place other than the bathroom at } \\
\text { my work to pump breast milk. }\end{array}$ & & .771 \\
\hline $\begin{array}{l}\text { 10- My workplace has a refrigerator that I can use to store my } \\
\text { milk. }\end{array}$ & & .631 \\
\hline $\begin{array}{l}\text { 11- My workplace has a breast pump for nursing mothers to } \\
\text { use }\end{array}$ & & .689 \\
\hline 12- My workplace or around has an on-site daycare. & & .498 \\
\hline Variance explained \% & 28.024 & 19.712 \\
\hline Total variance explained \% & 28.024 & 47.736 \\
\hline
\end{tabular}

The components making up the two-factor structure of the WBSS were examined, and the factors were named. After it was determined that the 12-item WBSS had a 2 -factor structure, the factors were named (Table 2).

Table 3. Model fit indices

\begin{tabular}{|l|l|l|l|}
\hline Index & Good Fit & Acceptable Fit & Fit Index of the Model Değerleri \\
\hline$(\mathrm{X} 2 / \mathrm{sd})$ & $\leq 3$ & $\leq 4-5$ & 1.928 good fit \\
\hline RMSEA & $\leq .05$ & $.06-.08$ & .064 acceptable fit acceptable fit um \\
\hline SRMR & $\leq .05$ & $.06-.08$ & .075 acceptable fit \\
\hline
\end{tabular}




\begin{tabular}{|l|l|l|l|}
\hline NFI & $\geq .95$ & $.94-.90$ & .861 acceptable fit \\
\hline CFI & $\geq .97$ & $\geq .95$ & .962 acceptable fit \\
\hline GFI & $\geq .90$ & $.89-.85$ & .929 good fit \\
\hline AGFI & $\geq .90$ & $.89-.85$ & .896 acceptable fit \\
\hline TLI & $\geq .95$ & $.94-.90$ & .908 acceptable fit \\
\hline
\end{tabular}

CFA methods were applied to test the suitability of the 2-factor structure formed as a result of EFA. Whether the data deviated from the normal distribution was evaluated by the Z-test. SEM was performed to confirm the 2-factor structure of the scale (Table 3). In general, it was observed that the model had the desired level of fit values. The tested two-factor model is introduce in figure 2 all paths in the model were found to be significant at the 0.001 level.

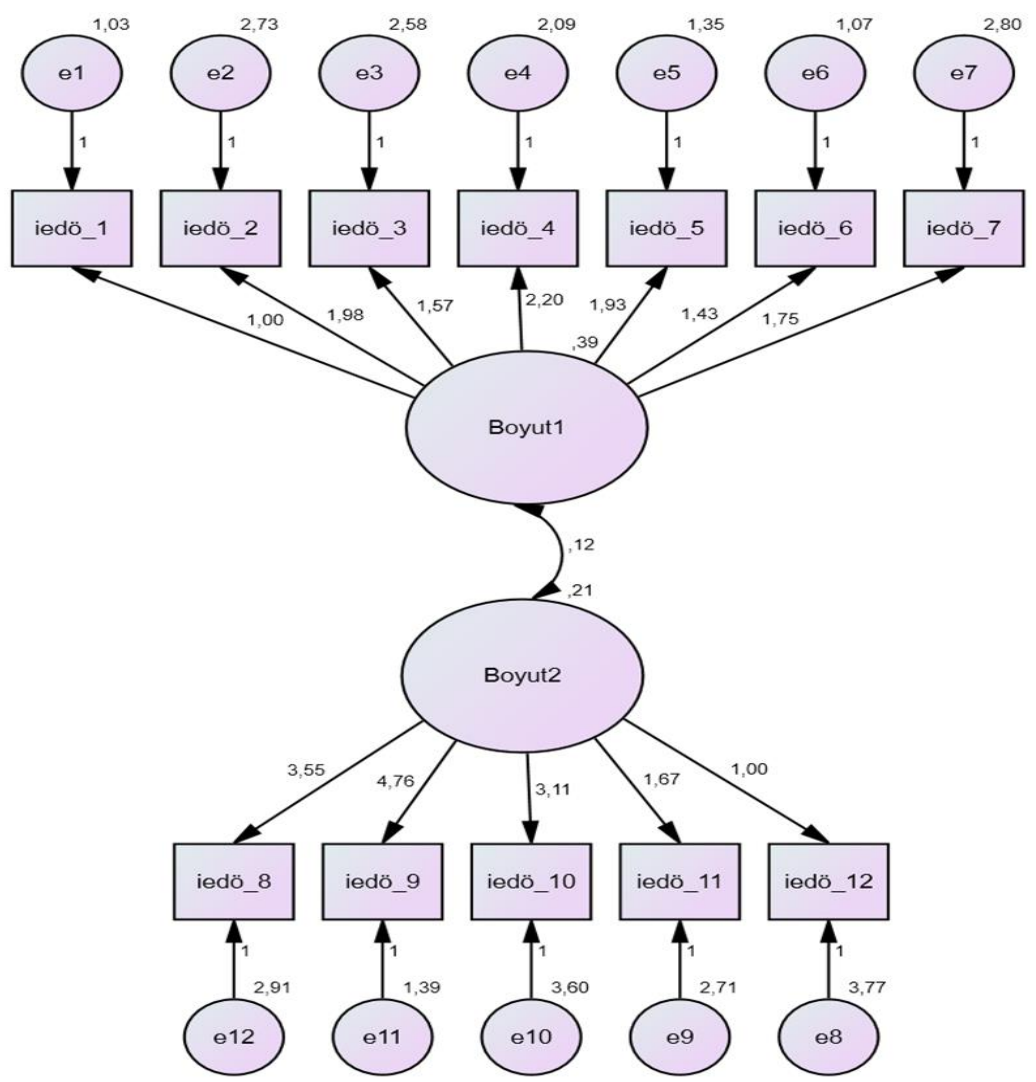

Figure 2. Confirmatory factor analysis model of the WBSS 
After the total scores in the scale were sorted from the largest to the smallest, $27 \%$ slices were taken from the lower group and the upper group and $t$ values were calculated for each item. The difference between the subgroup and the supergroup dec significant for all WBSS elements $(\mathrm{p}<0.00)$.

Table 4. Cronbach's alpha coefficient of the workplace breastfeeding support scale

\begin{tabular}{|c|c|c|c|c|c|c|}
\hline $\begin{array}{l}\text { Item } \\
\text { number }\end{array}$ & $\begin{array}{l}\text { Arithmetic } \\
\text { mean }\end{array}$ & $\begin{array}{l}\text { Standard } \\
\text { deviation }\end{array}$ & $\begin{array}{l}\text { Scale mean } \\
\text { if deleted }\end{array}$ & $\begin{array}{l}\text { Scale } \\
\text { variance } \\
\text { if item } \\
\text { deleted }\end{array}$ & $\begin{array}{l}\text { Corrected } \\
\text { item -total } \\
\text { correlation }\end{array}$ & $\begin{array}{l}\text { Cronbach's } \\
\text { coefficient if } \\
\text { item deleted }\end{array}$ \\
\hline 1 & 6.35 & 1.19 & 48.48 & 150.45 & .334 & .769 \\
\hline 2 & 5.30 & 2.07 & 49.53 & 135.58 & .453 & .756 \\
\hline 3 & 5.80 & 1.89 & 49.04 & 141.20 & .377 & .764 \\
\hline 4 & 5.20 & 2.00 & 49.64 & 132.02 & .558 & .745 \\
\hline 5 & 5.73 & 1.68 & 49.11 & 138.56 & .514 & .752 \\
\hline 6 & 6.00 & 1.37 & 48.84 & 144.43 & .467 & .759 \\
\hline 7 & 5.07 & 2.00 & 49.77 & 138.34 & .409 & .761 \\
\hline 8 & 2.68 & 2.36 & 52.16 & 128.34 & .519 & .748 \\
\hline 9 & 3.81 & 2.48 & 51.02 & 122.72 & .596 & .737 \\
\hline 10 & 4.84 & 2.38 & 50.00 & 133.75 & .405 & .763 \\
\hline 11 & 1.84 & 1.82 & 53.00 & 145.21 & .300 & .772 \\
\hline 12 & 2.22 & 2.00 & 52.61 & 152.71 & .100 & .793 \\
\hline \multirow[t]{2}{*}{ Scale } & $\begin{array}{l}\text { Arithmetic } \\
\text { Mean }\end{array}$ & Variance & $\begin{array}{l}\text { Standard } \\
\text { Deviation }\end{array}$ & $\begin{array}{l}\text { İtem } \\
\text { number }\end{array}$ & $\begin{array}{l}\text { Cronbach } \\
\text { Alfa }\end{array}$ & Ranj \\
\hline & 109.04 & 39.372 & 6.28 & 12 & .776 & 34 \\
\hline
\end{tabular}

To evaluate the internal consistency of the WBSS, Cronbach's alpha coefficient, item-total score correlations, and split-half technique methods were applied. Cronbach's alpha coefficient of the scale was found to be 0.78 . The 12 th item of the WBSS was below the critical value (0.30). In the 12 th item of the scale, there is the statement, "There is a daily child care service in or around my workplace." When the distribution of the responses given to this item was examined, it was observed that the option "Strongly disagree" was marked with $65.8 \%$. Since the daily child care service referred to in this item is not widespread in our country, this result is natural for this item. Furthermore, it can be observed from the table that Cronbach's alpha coefficient of the scale was above the critical value with 0.78 , and when the 12th item was removed, Cronbach's alpha coefficient increased to 0.79 (Table 4). Therefore, it was decided that there was no need to remove the 12 th item from the scale. It was determined that the correlation coefficients of the items of the 
WBSS ranged between 0.255 and 0.715 , and the item-total score correlations were highly significant $(\mathrm{p}<0.001)$. When the split-half reliability values of the WBSS were examined, Cronbach's alpha coefficient of the first half value was calculated as 0.78 , and Cronbach's alpha coefficient of the second half value was calculated as 0.68 . The split-half correlation values were calculated as the Spearman-Brown coefficient of 0.533 and the Guttman split-half coefficient of 0.530 .

Table 5. Correlation between pretest and posttest scores

\begin{tabular}{|l|l|l|}
\hline & r & p \\
\hline Pre-test & \multirow{2}{*}{.932} & \\
\cline { 1 - 1 } Post-test & & .000 \\
\hline
\end{tabular}

Correlation analysis and Pearson's product-moment analyses were completed to define the time invariance of the WBSS. The correlation value of the relationship between the pre-test and post-test measurement results was $r=0.932$, and $p<0.001$ was found to be significant (Table 5).

The correlation values of the WBSS sub-dimensions were found to be highly significant $(\mathrm{p}<0.001)$. The sub-dimensions of the scale and Cronbach's alpha and range values of the total score were examined. Cronbach's alpha value of the first factor was found to be 0.795 , the required range was 42 , and the calculated range was 40 . Cronbach's alpha value of the second factor was 0.713 , the required range was 30 , and the calculated range was 30 . Cronbach's alpha value of the total score was 0.776 , the required range was 72 , and the calculated range was 62 . These results show that the WBSS has a 2 -factor structure and reveal that the scale can be used in this way.

\section{DISCUSSION}

The WBSS, which was introduced to the literature by Bai et al., is used to determine the degree of breastfeeding support in the workplace from the point of view of returning mothers (Bai et al., 2008). Considering that there was a need for a valid measurement tool to evaluate the perception of working mothers regarding breastfeeding support in the workplace in Turkey, it was aimed to perform the Turkish adaptation, validity and reliability studies of the WBSS.

The standard approach in scale adaptation studies is to first evaluate the psycholinguistic features of the scale (translation, expert opinion, pilot study) and then evaluate the psychometric features of the scale (Karaçam, 2019).

One of the methods used to test content validity is to receive expert opinions. 
It is stated to be very important that the number and quality of experts be between 5 and 40 (Büyüköztürk, 2006; Esin, 2014). Nine expert opinions were received to evaluate the WBSS content in the study, and they were asked to make an evaluation using the Davis technique. The CVI is expected to be 0.80 and above (Rubio et al., 2003). It was determined that the CVI score of the current scale was 0.97 , and the scale provided the content validity.

KMO test, which measures the suitability of factor analysis and the correlations between variables, and Bartlett's test, which measures the statistical significance of this correlation matrix, are performed (Büyüköztürk, 2002; Yaşlığlu, 2017). The value of the KMO test should be 0-1 (Yaşloğlu, 2017). The KMO value of this study was calculated as 0.797 . According to this result, the sample size for factor analysis is at a good level. Bartlett's test examines whether the correlation matrix is proportional to a unit matrix (Field, 2005). In the study, the values of $\chi^{2}=717.023$ and $\mathrm{p}<0.05$ were determined. These results reveal the applicability of the data for factor analysis.

Principal component and Varimax rotation methods, which are EFA methods, were related to the WBSS. The total variance was found to be $47.736 \%$. It is stated that in order for the variance to be sufficient in the scales, the variance should be $40 \%-60 \%$ (Çokluk et al., 2010). In this context, it is observed that the scale is sufficient. A minimum of 0.30 is recommended for factor loads to be acceptable (Hair et al., 1992). It was determined that the factor loads of all items were above 0.30 . With the present results, it was determined that the construct validity of the WBSS was suitable.

In the split-half method, the items in the scale are divided into two parts, and the scores on one half of the scale are associated with the scores on the other half of the scale, and alpha values are found (Chakrabartty, 2013; Kalayc1, 2005). The alpha value of the split-half coefficient of the WBSS was determined as $0.781,0.689$ for the first half and the second half, the total value was 0.689 , and the correlation coefficient between the first half and second half was 0.36 . It was determined that the Spearman-Brown coefficient of the scale was 0.53 and the Guttman split-half coefficient was 0.53 . The results indicate that the internal consistency reliability of the WBSS is high.

There are different methods for determining item statistics during item analysis. In the simple method, the scores obtained from the measurement tool are ordered from the largest to the smallest, and the subgroup and the supergroup are determined as $27 \%$ subgroup score with the lowest score and $27 \%$ supergroup score with the highest score (Hasançebi et al., 2020). Whether each scale item distinguishes the two groups in the current scale was evaluated with the t-test, and it was 
determined that the test value was significant at the $\mathrm{p}<0.05$ significance level. The results reveal that all items and the total score of the scale distinguish those with high WBSS scores from those with low WBSS scores.

CFA is completed to test the validity of the structure obtained after explanatory factor analysis (Orçan, 2018). SEM is a statistical statement about the correlations between variables, and the path diagram is a pictorial representation of the model (Suhr, 2006). In the literature, the $\chi 2$ degree of freedom (df) ratio is used as a criterion for qualification (Çokluk et al., 2010). In the present study, the value of $\chi^{2} / \mathrm{df}$ $=1.928$ was determined. These results indicate that the WBSS showed an excellent fit.

There are various fit indices other than the $\chi 2$ test in the evaluation of model fit (İlhan \& Çetin, 2014). The SRMR is an absolute fit index and indicates excellent model fit. It is indicated by $\mathrm{RMR}=0$, and higher values indicate a poor fit (Kline, 2005). In the present study, it was calculated as SRMR $=0.075, \mathrm{RMSEA}=0.064$, $\mathrm{AGFI}=0.896, \mathrm{NFI}=0.861, \mathrm{GFI}=0.929, \mathrm{CFI}=0.962$, and TLI $=0.908$. In general, it shows that the model has the desired level of fit values, and the model provides construct validity.

The invariance of a measurement tool is the degree to which similar results are obtained in two separate situations. Reliability estimation focuses on the tool's sensitivity to extraneous effects such as participant fatigue over time. Invariance evaluations are made by test-retest reliability procedures. Researchers apply the same measure to a sample twice and then compare the scores. In the present study, Pearson's product-moment correlation analysis was applied to evaluate invariance(Denise F. P. \& Beck, 2010). A minimum value of 0.70 is considered sufficient for the interpretation of the results (Souza et al., 2017). In the study, the correlation value for the relationship between the two measurements was determined to be $\mathrm{r}=0.932$ and $\mathrm{p}<0.001$. The results reveal that the results of the scale performed at 15-day intervals are similar and sufficient in terms of time invariance.

Consistency between the scores obtained at different and same times are the two main criteria sought for the reliability of the measurement tool. "Split-half method, Cronbach's alpha coefficient, Kuder-Richardson coefficient and item-total score scale reliability-coefficient of concordance" are the main reliability test types (Büyüköztürk, 2006). Internal consistency between all items is calculated by Cronbach's alpha coefficient (Şeker \& Gençdoğan, 2020). The reliability of the scale is interpreted according to Cronbach's alpha coefficient, and the alpha coefficient is expressed with high reliability between $0.80 \leq a<1.00$, substantial reliability between $0.60 \leq \alpha<0.80$, poor reliability between $0.40 \leq \alpha<0.60$, and unreliability between $0 \leq a<0.40$ (Kalayc1, 2005; Kiliç, 2016). In the current study, when 
Cronbach's alpha values of the WBSS subscales and the total score were examined, it can be said that Cronbach's alpha value for the Peer and Environmental Support sub-dimension is 0.80 , Cronbach's alpha value for the Workplace Support and Technical Support sub-dimension is 0.71 , Cronbach's alpha value of the total score is 0.78 , and with regard to these values, the reliability of the scale is high. Cronbach's alpha coefficient value of the WBSS developed by Bai et al. was found to be 0.77 (Bai et al., 2008). According to Martin et al.in their study with mothers who served as soldiers, the Chronbach's Alpha coefficient value of the scale used was found to be 0.85 (Martin, 2015). Since the reliability level of the WBSS was found to be substantially reliable at a rate similar to the results obtained in the original scale, the scale adapted into Turkish was found to be substantially reliable. For internal consistency reliability, the average of the item-total score correlation coefficients is calculated (Çakmur, 2012). If the mean of the item-total score correlation coefficients is high and positive, it indicates that the scale items exemplify similar behaviors and that the internal consistency of the test is high (Büyüköztürk, 2006). Generally, the item-total score correlation of 0.00 or (-) is interpreted as no distinctiveness, $0.00-0.19$ is interpreted as low distinctiveness, $0.20-0.39$ is interpreted as moderate distinctiveness, and 0.40-1.00 is interpreted as good distinctiveness (Şeker \& Gençdoğan, 2020). In the current study, it was determined that the total correlations of all the scale items of the WBSS were between 0.26 and 0.72 . It was found that the 2 nd item of the WBSS had a moderate item-total score correlation and all other items were at a good level. However, these results reveal that the WBSS, which consists of 12 items, does not have a problematic item.

\section{CONCLUSION AND SUGGESTIONS}

It was defined that the WBSS is a valid and reliable measurement tool in determining the perception of workplace breastfeeding support in working mothers in Turkish society. The scale consists of 12 items. The scale has two sub-dimensions. It was determined that the lowest score that could be obtained from the Peer and Environmental Support dimension was 7 and the highest score was 49, while the lowest score that could be obtained from the Facility Support and Technical Support dimension was 5 and the highest score was 35. The WBSS does not have a reverse item. As the scores obtained from the scale increase, the perception of workplace breastfeeding support in working mothers increases. It is recommended that the WBSS, which was adapted into Turkish, should be tested in mothers working outside the public sector or in different samples.

\section{Acknowledgments}

The authors would like to thank working mothers for their participation in this research. 


\section{Conflict Of Interest Statement}

\section{The authors report no actual or potential conflicts of interest.}

\section{Author Contribution}

Study concept/Design: N.K., M.K., Data collection: N.K., Data analysis and interpretation: N.K.,M.K., Draft manuscript: N.K., M.K., Approval of final manuscript: N.K., M.K., Supervision/Advisory: N.K, M.K.

\section{REFERENCES}

ACOG. (2016). Optimizing support for breastfeeding as part of obstetric practice. Committee Opinion No. 658. Obstet Gynecol, 127(2), e86-e92.

Anderson, J., et al. (2015). Policies aren't enough: The importance of interpersonal communication about workplace breastfeeding support. Journal of Human Lactation, 31(2), 260-266.

Bai, Y., Peng, C.-Y. J., \& Fly, A. D. (2008). Validation of a short questionnaire to assess mothers' perception of workplace breastfeeding support. Journal of the American Dietetic Association, 108(7), 1221-1225.

Bai, Y., \& Wunderlich, S. M. (2013). Lactation accommodation in the workplace and duration of exclusive breastfeeding. Journal of midwifery \& women's health, 58(6), 690-696.

Bruk-Lee, V., Albert, D., \& Stone, K. L. (2016). Lactation and the working woman: Understanding the role of organizational factors, lactation support, and legal policy in promoting breastfeeding success. In research perspectives on work and the transition to motherhood (pp. 217-239). Springer.

Büyüköztürk, Ş. (2002). Faktör analizi: Temel kavramlar ve ölçek geliştirmede kullanımı. Kuram ve Uygulamada Egitim Yönetimi Dergisi, 8(4), 470-483.

Büyüköztürk, Ş. (2006). Sosyal Bilimler için Veri Analizi El Kitabı Istatistik, Araştırma Deseni SPSS Uygulamaları ve Yorum. Pegem Akademi Yayıncılık, Ankara.

Chakrabartty, S. N. (2013). Best split-half and maximum reliability. IOSR Journal of Research \& Method in Education, 3(1), 1-8.

Çakmur, H. (2012). Araştırmalarda ölçme-güvenilirlik-geçerlilik. TAF Preventive Medicine Bulletin, 11(3).

Çokluk, Ö., Şekercioğlu, G., \& Büyüköztürk, Ş. (2010). Sosyal bilimler için çok değişkenli istatistik: SPSS ve LISREL uygulamaları. Pegem Akademi Yayıncilık, Ankara.

Denise F. Polit, \& Beck, C. T. (2010). Essentials of Nursing Research: Appraising Evidence For Nursing Practice (7th Ed. ed.). Wolters Kluwer and Lippincott Williams and Wilkins.

Eidelman, A. I., \& Schanler, R. J. (2012). Breastfeeding and the use of human milk. Pediatrics. https://psycnet.apa. огg/doi/10.1542/peds.2011-3552

Eren, T., et al. (2018). Kadın hekimlerin emzirme deneyimleri ve yasa değişikliğinin emzirme üzerindeki etkisi. Türk Pediatri Arşivi, 53(4), 238-244.

Eroğlu, V., \& Yurtsal, Z. B. (2018). Emzirme ve çalışma hayatı. In Z. B. Yurtsal (Ed.), Anne Sütü ve Emzirmede Kanıt Temelli Uygulamalar. Anadolu Nobel Tip Kitabevleri.

Esin, M. N. (2014). Veri toplama yöntem ve araçları \& veri toplama araçlarının güvenirlik ve geçerliği. Erdoğan S, Nahçivan N, Esin MN. Hemşirelikte Araştırma: Süreç, Uygulama ve Kritik, İstanbul: Nobel Tıp Kitapevi, 217-230.

Field, A. (2005). Discovering Statistics Using SPSS. London: SAGE Publications. Anuario de psicología/The UB Journal of psychology, 37(1), 195-196.

Gianni, M. L., et al. (2019). Breastfeeding Difficulties and Risk for Early Breastfeeding Cessation. Nutrients, 11(10).

Hair, J., et al. (1992). In Easter, R.(ed.) Multivariate Data Analysis: With Readings. In. New York: Macmillan Publishing company.

Hasançebi, B., Terzi, Y., \& Küçük, Z. (2020). Madde güçlük indeksi ve madde ayırt edicilik indeksine dayalı çeldirici analizi. Gümüşhane Üniversitesi Fen Bilimleri Enstitüsü Dergisi, 10(1), 224-240.

Haviland, B., et al. (2015). Supporting breastfeeding in the workplace. Australasian Journal of Early Childhood, 
38(3), 118-119.

Ilthan, M., \& Çetin, B. (2014). LISREL ve AMOS programları kullanılarak gerçekleştirilen yapısal eşitlik modeli (yem) analizlerine ilişkin sonuçların karşılaştırılması. Journal of Measurement and Evaluation in Education and Psychology, 5(2), 26-42.

Kalaycı, Ş. (2005). SPSS uygulamalı çok değişkenli istatistik teknikleri [SPSS applied multivariate statistical techniques ] (Vol. 5). Asil Yayın Dağıtım

Karaçam, Z. (2019). Ölçme Araçlarının Türkçeye Uyarlanması. Ebelik ve Sağık Bilimleri Dergisi, 2(1), 28-37.

Kiliç, S. (2016). Cronbach's alpha reliability coefficient. Psychiatry and Behavioral Sciences, 6(1), 47.

Kim, J. H., Shin, J. C., \& Donovan, S. M. (2019). Effectiveness of workplace lactation interventions on breastfeeding outcomes in the United States: an updated systematic review. Journal of Human Lactation, 35(1), 100-113.

Kline, R. B. (2005). Principles and practice of structural equation modeling (Second ed.). Guilford publications.

Lee, J. (2017). Supporting breastfeeding moms at work: How a doctor's note can make the difference. Breastfeeding Medicine, 12(8), 470-472.

Martin, S. E., et al. (2015). Active duty women's perceptions of breast-feeding support in the military setting. Military Medicine, 180 (11), 1154-1160.

Orçan, F. (2018). Exploratory and confirmatory factor analysis: which one to use first? journal of Measurement and Evaluation in Education and Psychology, 9(4), 414-421.

Rubio, D. M., et al. (2003). Objectifying content validity: Conducting a content validity study in social work research. Social work research, 27(2), 94-104.

Souza, A. C. d., Alexandre, N. M. C., \& Guirardello, E. d. B. (2017). Psychometric properties in instruments evaluation of reliability and validity. Epidemiologia e Serviços de Saúde, 26, 649-659.

Suhr, D. (2006). The basics of structural equation modeling. Retrieved 1 Eylül 2021, from http://www.lexjansen. com/wuss/2006/tutorials/TUT-Suhr.pdf

Şeker, H., \& Gençdoğan, B. (2020). Psikolojide ve eğitimde ölçme aracı geliştirme (Third ed.). Nobel Akademik Yayıncilik.

UNICEF. (2017, 7 February 2019). The Global Breastfeeding Collective. Retrieved 17 Haziran 2020 from https://www. unicef.org/nutrition/index_98470.html

UNICEF. (2019). Aile dostu politikaların anne sütüyle besleme oranlarını tüm dünyada artırma açısından önemi. https://www.unicef.org/turkey/bas\%C4\%B1n-b\%C3\%BCltenleri/unicef-aile-dostu-politikalar\%C4\%B1nanne-s\%C3\%BCt\%C3\%BCyle-besleme-oranlar\%C4\%B1n\%C4\%B1-t\%C3\%BCm-d\%C3\%BCnyada

Yaşlıŏlu, M. M. (2017). Sosyal bilimlerde faktör analizi ve geçerlilik: Keşfedici ve doğrulayıcı faktör analizlerinin kullanılması. İstanbul Üniversitesi Işletme Fakültesi Dergisi, 46, 74-85. 